\title{
Compressive Strength Evaluation of Concrete with Palm Tree Ash
}

\author{
Saleh M. Alogla*, Ahmed I. Almusayrie \\ Department of Civil Engineering, College of Engineering, Qassim University, Buraydah, Saudi Arabia
}

Received January 4, 2022; Revised February 25, 2022; Accepted March 7, 2022

\section{Cite This Paper in the following Citation Styles}

(a): [1] Saleh M. Alogla, Ahmed I. Almusayrie , "Compressive Strength Evaluation of Concrete with Palm Tree Ash," Civil Engineering and Architecture, Vol. 10, No. 2, pp. 725-733, 2022. DOI: 10.13189/cea.2022.100227.

(b): Saleh M. Alogla, Ahmed I. Almusayrie (2022). Compressive Strength Evaluation of Concrete with Palm Tree Ash. Civil Engineering and Architecture, 10(2), 725-733. DOI: 10.13189/cea.2022.100227.

Copyright $@ 2022$ by authors, all rights reserved. Authors agree that this article remains permanently open access under the terms of the Creative Commons Attribution License 4.0 International License

\begin{abstract}
Concrete industry produces high carbon dioxide emissions that are harmful to the environment. As cement is the primary artificial component of concrete, most of the past studies focused on reducing the cement content in concrete manufacturing. To enhance the sustainability of concrete production, generally, cement is partially replaced with waste materials with similar characteristics such as silica fume and fly ash. One of the sources of such waste materials in date-producing countries is palm trees since each palm tree produces approximately $23 \mathrm{~kg}$ of waste annually. Currently, very limited use of palm tree waste exists in the concrete industry; specifically, palm tree leaves ash (PTA). This study is intending to evaluate the potential of adding PTA to concrete as a cement replacement by evaluating the compressive strength of PTA concrete. Several concrete cylindrical specimens were cast with variable percentages of added PTA. Three dosages of PTA (5\%, 10\%, and 15\%) were added to the concrete as a substitute for cement by weight. The palm tree ash added to concrete was collected from burned palm tree branches and filtered based on its fineness. Assessment of the compressive strength of PTA-based concrete was performed at ages of 7, 28, and 56 days. The results of evaluating the compressive strength of the specimens showed that the concrete mixed with only $5 \%$ PTA possesses around 12\% higher compressive strength than that without PTA. Further, increasing the dosage of added PTA to concrete yielded unfavorable results in terms of increasing the compressive strength. The addition of more than $10 \%$ of PTA to concrete as a replacement for cement triggered a significant reduction in compressive strength of the concrete. The findings of this
\end{abstract}

study encourage partial replacement of cement with PTA in concrete up to $5 \%$ to reduce concrete carbon footprint and enhance sustainability of concrete manufacturing process with maintaining desired mechanical properties.

Keywords Concrete, Compressive Strength, Cement, Palm Tree Leaves Ash (PTA), Carbon Dioxide

\section{Introduction}

Concrete is one of the most used construction materials in modern society and just second to water as the most consumed material worldwide [1]. Concrete construction, however, possesses a high carbon footprint and is deemed by the majority to be harmful to the environment [2]. As cement is the main artificial component of concrete most of the past research focused on reduction of the cement content in concrete manufacturing. The global production of cement was estimated to be around 4.1 billion tons in 2019 [3]. This high cement manufacturing is responsible for around $7 \%$ of the $\mathrm{CO}_{2}$ emissions among all human activities $[4,5]$. For each ton of manufactured cement, approximately 0.54 tons of $\mathrm{CO}_{2}$ is emitted into the environment [6].

The excessive use of cement steered many inventions in the concrete industry to partially replace cement with supplementary materials such as fly ash and silica fume or even to abandon cement entirely such as in geopolymer concrete and alkali-activated binders $[1,7,8]$. In addition to partially replacing cement in concrete, many studies 
investigated the use of recycled aggregates and waste materials as aggregates in concrete $[9,10]$. Other trends on reducing the environmental impact of concrete were directed to energy-saving concepts such as using alkali-activated binders to reduce the thermal conductivity of concrete or introducing light-transmitting concrete to reduce the costs of illumination $[11,12]$.

For cement replacement, different natural ashes were studied including rice husk ash, wood ash, and oil palm ash [13-16]. Most of the previous studies evaluated the mechanical performance and durability of concrete with such natural ashes. The addition of rice husk ash, up to $15 \%$ replacement for cement, increases the compressive strength of concrete by about 20\% [13]. The compressive strength of concrete marginally decreased with increasing the wood ash from 0 to $30 \%[14,15]$. Similarly, the current study aims to assess the potential of partially replacing cement in concrete with waste from palms and study its impact on compressive strength of concrete.

Most of the palm's waste, in Saudi Arabia and date-producing countries, is in the form of palm tree branches that are traditionally cut down and then burned in farms to ash as shown in Fig.1. This initial shape of the burned product is also shown in Fig. 2. These burned palm tree branches were utilized to filter palm tree ash for adding it to concrete as a cement substituting material. Thus, reducing cement and consequently limiting the impact of its manufacturing process on the environment.

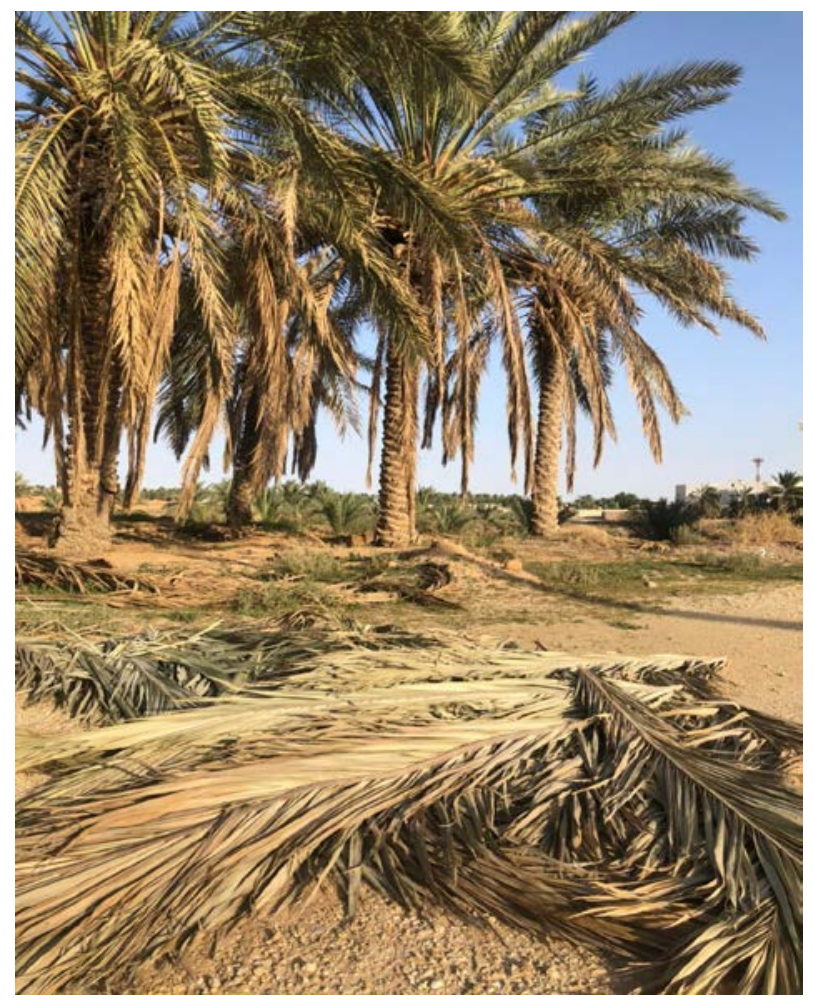

Figure 1. Trimmed dry leaf (palm branches) before the process of burning to ash and disposing

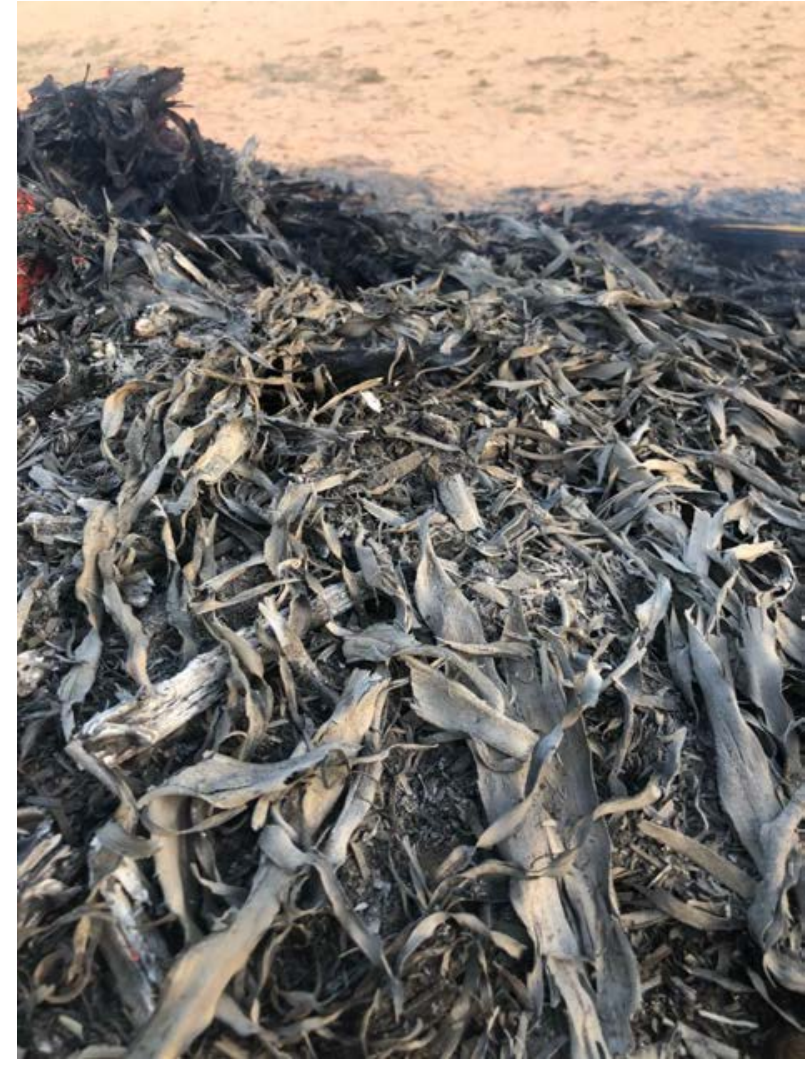

Figure 2. The initial shape of the burned palm tree branches

The benefits from utilizing agricultural waste (palm tree branches) after burning to reduce cement content in concrete are significant. It will provide a promise for recycling these cut-down branches, and therefore, reducing their burning impact on the region's atmosphere. The burning process can then be performed by the concrete manufacturing plant in a controlled environment, thus, reducing carbon dioxide emissions from traditionally burning palm tree branches in open areas around date farms. At present, PTA is rarely utilized for recycling purposes in Saudi Arabia. Its use is limited to coal-cubes-producing factories only. Incorporating PTA in the concrete industry is only at the research stage.

Al-Kutti, Saiful Islam, and Nasir $[17,18]$ examined the potential of using PTA in cement-based materials. The feasibility of incorporating PTA in concrete was evaluated by assessing strength, durability, and characterization. Cement mortar specimens were cast to evaluate compressive strength. Mortar and concrete specimens were also used to evaluate the rate of water absorption, rapid chloride permeability, and hydration products by thermogravimetric analysis. The selected doses of PTA in these studies were $10 \%, 20 \%, 30 \%$ as a replacement for Ordinary Portland Cement (OPC). Palm tree branches waste material (PTA) was obtained from local factories during the production of charcoal and firewood which is resulting from the process of burning the raw waste material in an oven for 7 hours. Mortar and concrete samples were cast from the reference ordinary concrete and 
the three types of PTA dosed concrete. The study results showed that the mixture prepared with a dose of $10 \%$ of PTA as partial replacement of cement in mortar and concrete, improved overall quality of both the environment and concrete. This conclusion is supported by showing that the mortar and concrete specimens with $10 \%$ replacement of cement by PTA formed more hydration products, calcium silicate hydrate (CSH) and calcium aluminosilicate hydrate (CASH), in cement paste and concrete as compared to OPC specimens. The chemical composition of PTA was also analyzed and found to be similar to that of Portland cement to a certain degree.

Portland cement is mainly composed of four compounds including tricalcium silicate $\mathrm{C}_{3} \mathrm{~S}$, dicalcium silicate, $\mathrm{C}_{2} \mathrm{~S}$, tricalcium aluminate $\mathrm{C}_{3} \mathrm{~A}$, and tetracalcium aluminoferrite $\mathrm{C}_{4} \mathrm{AF}$. The first two of these compounds, $\mathrm{C}_{3} \mathrm{~S}$ and $\mathrm{C}_{2} \mathrm{~S}$, are responsible for hydration and hardening of cement as well as its initial setting and early strength [19].

The main components in chemical reactions of $\mathrm{C}_{3} \mathrm{~S}$ and $\mathrm{C}_{2} \mathrm{~S}$ compounds (also called phases of cement manufacturing) are silicate dioxide $\mathrm{SiO}_{2}$ commonly abbreviated as $\mathrm{S}$, and calcium oxide $\mathrm{CaO}$ abbreviated as $\mathrm{C}$. Portland cement typically contains $20 \%$ of $\mathrm{SiO}_{2}$ and $63 \%$ of $\mathrm{CaO}$ whereas PTA contains $35.9 \% \mathrm{SiO}_{2}$ and $13.0 \% \mathrm{CaO}$ $[17,18]$. These two compounds hydrate with water to form calcium hydroxide and calcium silicate hydrate in the cement paste. Products of the hydration process are the building block of the concrete and cement strength and durability.

Amah et al. [20] presented a study on the effect of using palm leaf ash as a partial substitute for cement in improving workability and compressive strength of concrete. The study included a variation in two factors which are the water/cement (w/c) ratio and the content of palm leaf ash. The w/c ratio was ranged from 0.4 to 0.7 and two dosages (2\% and 5\%) of palm leaf ash were incorporated in this study as a replacement for cement. In evaluating the workability, both dosages were varied with different w/c ratios. For evaluating compressive strength, cubes were cast from each of the selected mixtures in the study. The study found that workability increased reasonably with the $5 \%$ addition of palm leaf ash. Further, the compressive strength was similar in the 14-day test of concrete specimens for both the cases of partial replacements of cement by $2 \%$ and $5 \%$ of palm leaf ash. However, for 28-day compressive strength, the addition of $5 \%$ palm leaf ash yielded higher compressive strength of concrete. The optimum variation which gave a compressive strength of $15.75 \mathrm{MPa}$ on day 14 and 17.69 MPa on day 28 was using a PTA of $5 \%$ and 0.55 w/c ratio.
Almulali et al. [16] presented a review on the incorporation of oil palm ash in concrete as a means of recycling. Other research studies also examined the potential of using oil palm tree waste in concrete [21-25]. Based on these studies, the possibility of studying a mixture of concrete with PTA at a smaller percentage (less than $15 \%$ ) will be valuable for the further implementation of these agricultural wastes in the concrete industry. In addition, limited studies have examined the compressive strength of concrete with palm tree ash that is locally available in Saudi Arabia. Most of these studies tested the compressive strength of mortar specimens $[17,18]$. The current study will mainly depend on an experimental regime that consists of testing compressive strength for several concrete cylindrical specimens with variable percentages of added PTA varied from 5\% to $15 \%$.

\section{Materials and Methods}

The experimental program consists of testing 36 concrete cylindrical specimens to assess the compressive strength of concrete and determine the optimal percentage of PTA to be added to concrete. Three amounts of PTA (5\%, $10 \%$, and $15 \%)$ were added to the concrete. These percentages of PTA were added as a substitute for cement by weight. The PTA is characterized by its fineness and the degree to which it was burned in terms of time and temperature.

\subsection{Utilized Materials}

The materials used in casting specimens consisted of Ordinary Portland Cement (Type I), conforming to ASTM C150, palm tree Ash (PTA) material produced from collecting palm tree dry leaves or branches and burning them. Natural clean sand was used as fine aggregate. The coarse aggregates were crushed stone with sizes $3 / 4$ inch and 3/8-inch conforming to ASTM C 33 [26].

The burning process followed in this study was performed to simulate the existing waste material (PTA) in farms as shown in Fig.3. The method was to burn the palm tree branches for approximately 20 minutes after which the fire is extinguished with water. The remaining burned leaves ash was dried out on a regular stove as shown in Fig.4. The resulting granular charcoal shape ash was grounded and then filtered using sieve No $40(420 \mu \mathrm{m})$ size to collect the final ash product. The resulting PTA from this process is shown in Fig.5 as compared to ordinary Portland cement. 


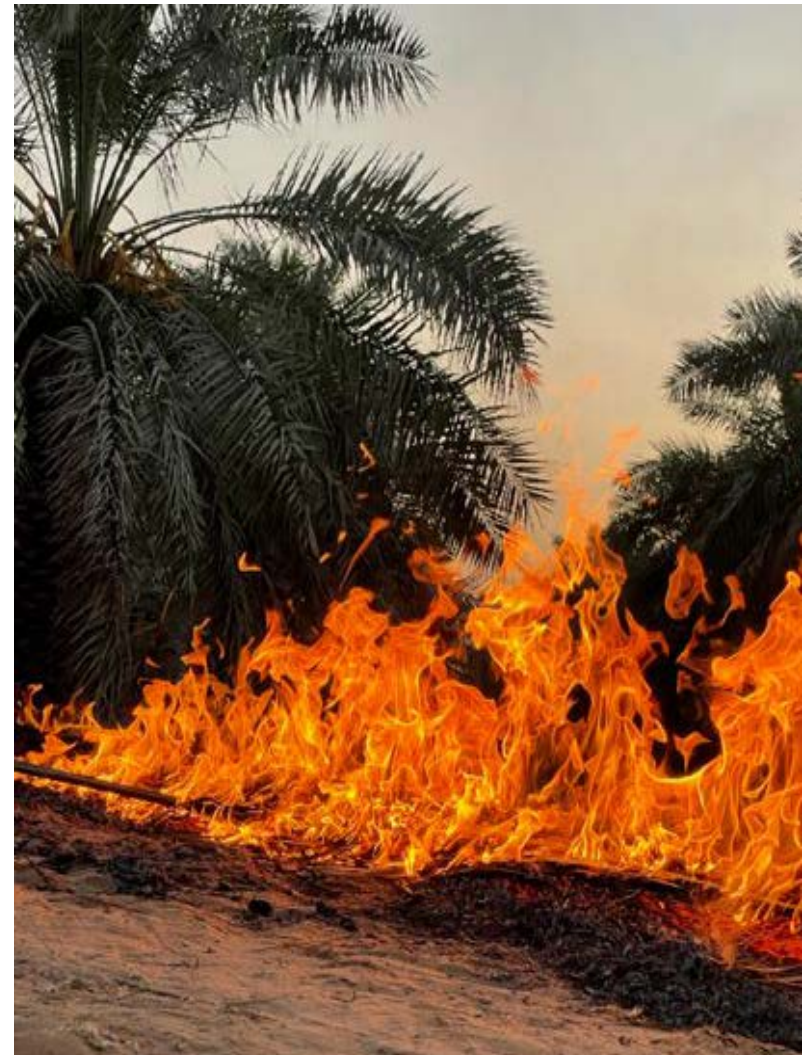

Figure 3. Typical burning process of palm tree branches

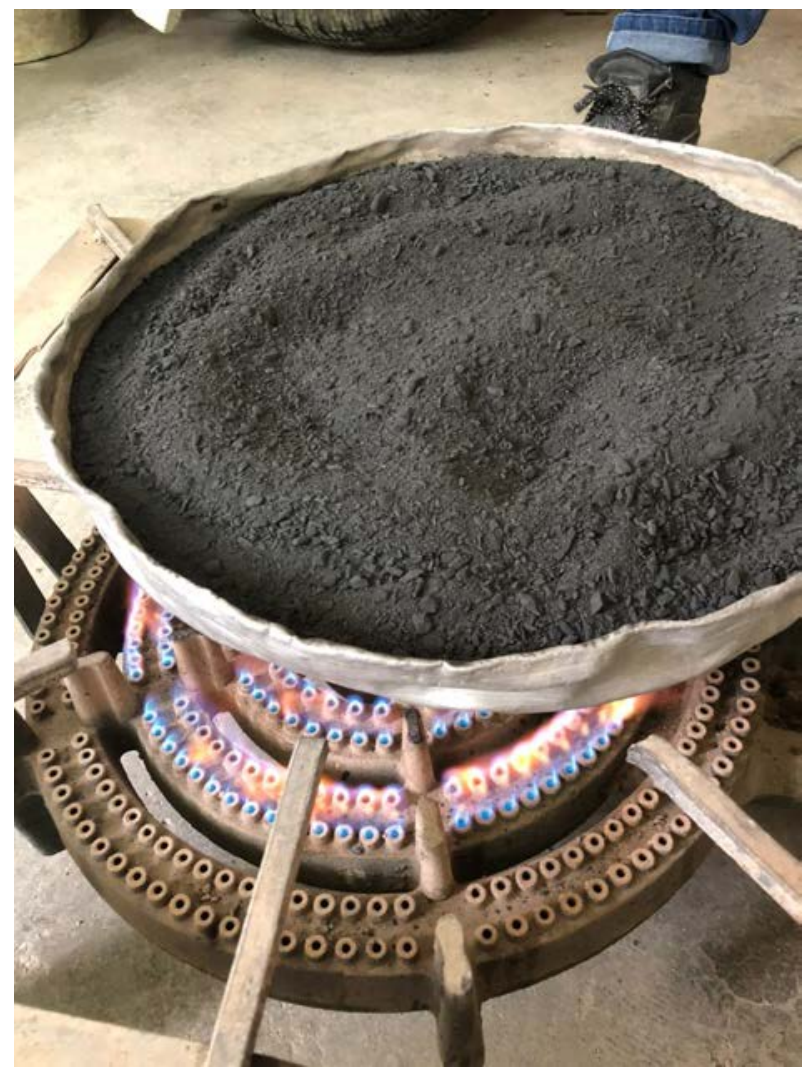

Figure 4. Palm tree ash drying after rinsing with water

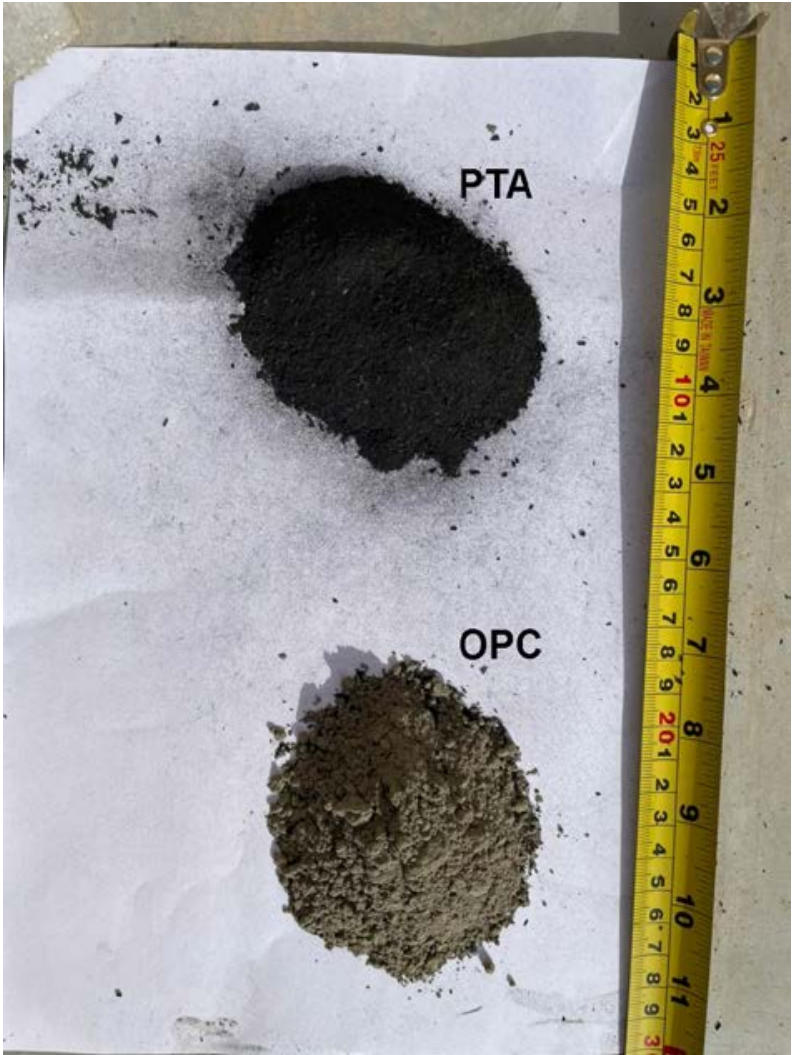

Figure 5. Utilized palm tree ash (PTA) on top compared to ordinary Portland cement (OPC) at the bottom of the picture

\subsection{Mixture Preparation}

Table 1. Concrete mix ratios used in the study and their slump and temperature values

\begin{tabular}{|c|c|c|c|c|}
\hline Constituent & $\begin{array}{c}\text { Mix 1 } \\
(\mathbf{0 \% )}\end{array}$ & $\begin{array}{c}\text { Mix 2 } \\
\mathbf{( 5 \% )}\end{array}$ & $\begin{array}{c}\text { Mix 3 } \\
\mathbf{( 1 0 \% )}\end{array}$ & $\begin{array}{c}\text { Mix 4 } \\
(\mathbf{1 5 \% )}\end{array}$ \\
\hline $\begin{array}{c}\text { Portland cement } \\
\text { Type I, Kg/ m }\end{array}$ & 450 & 427.5 & 405 & 382.5 \\
\hline $\begin{array}{c}\text { Palm tree ash, Kg/ } \\
\mathrm{m}^{3}\end{array}$ & 0 & 22.5 & 45 & 67.5 \\
\hline $\begin{array}{c}\text { Fine aggregate, Kg/ } \\
\mathrm{m}^{3}\end{array}$ & 672 & 672 & 672 & 672 \\
\hline $\begin{array}{c}\text { Coarse aggregate, } \\
\text { 3/8 in., Kg/ m }\end{array}$ & 397 & 397 & 397 & 397 \\
\hline $\begin{array}{c}\text { Coarse aggregate, } \\
\text { 3/4 in., Kg/ }{ }^{3}\end{array}$ & 596 & 596 & 596 & 596 \\
\hline Water, liters/ ${ }^{3}$ & 182 & 182 & 182 & 182 \\
\hline w/c & 0.40 & 0.42 & 0.45 & 0.48 \\
\hline Slump, mm & 190 & 180 & 160 & 140 \\
\hline Temperature, ${ }^{\circ} \mathrm{C}$ & 26.0 & 27.5 & 28.0 & 29.0 \\
\hline
\end{tabular}

Four concrete mixtures were designed for evaluating the compressive strength of concrete which include a mixture with 5\% PTA, 10\% PTA, and 15\% PTA as listed in Table 1. Mix 1 is the reference mixture used to produce control concrete specimens. The weight of added PTA is subtracted from the cement content of the reference mixture. Mixing of concrete was in an electronic mixer, and in accordance with ASTM C192 [27]. The initial 
cement content was selected to be $450 \mathrm{~kg} / \mathrm{m}^{3}$ to simulate concrete mixtures with high cement content and study the effect of cement replacement with PTA. The other components of the mixtures were fixed for all four mixtures to concentrate on the effect of replacing cement with PTA. The slump and temperature values for each concrete mixture are also reported in Table 1.

\subsection{Specimens Fabrication}

The reinforced concrete specimens were cast in standard cylindrical molds of $150 \mathrm{~mm}$ diameter and $300 \mathrm{~mm}$ height as shown in Fig.6. After casting, specimens were cured by submerging them into a water tank as shown in Fig.7 as per ASTM C511 standard [28].

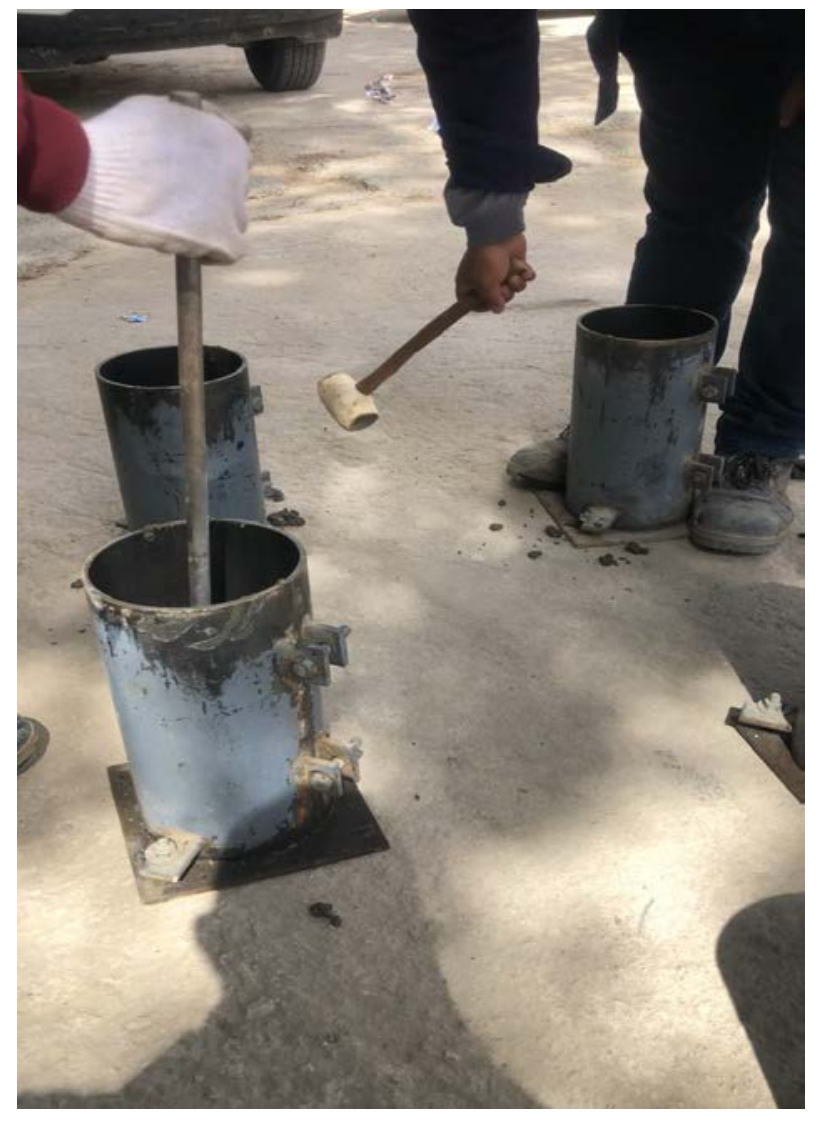

Figure 6. Cylindrical molds of $150 \mathrm{~mm}$ diameter and 300mm height

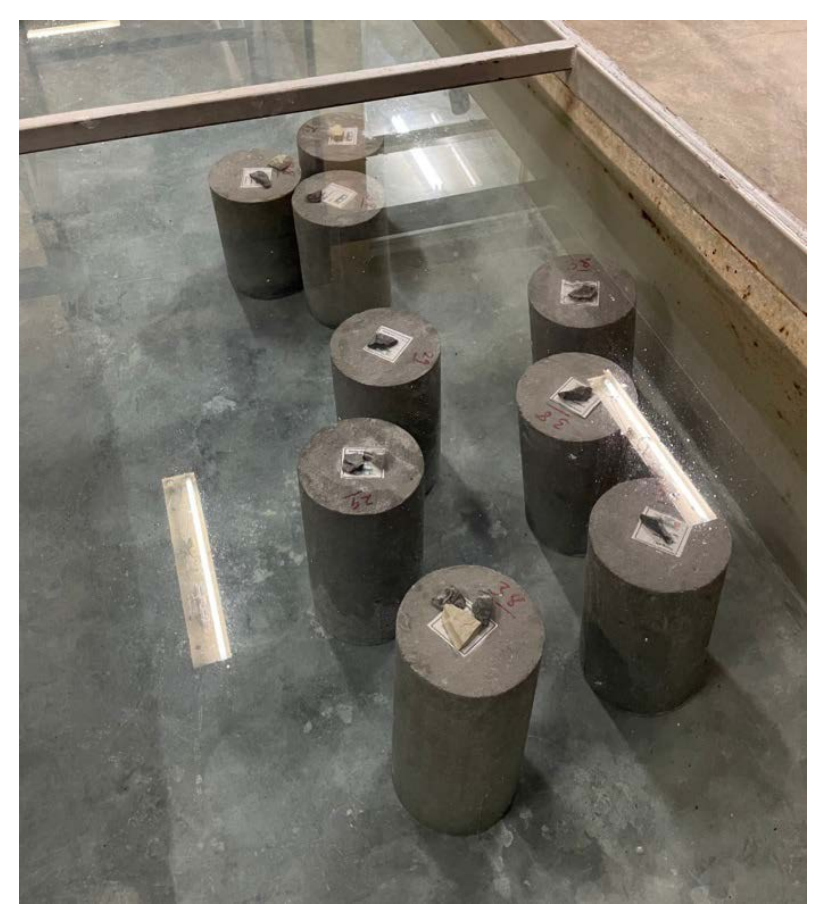

Figure 7. Specimens curing process in the water tank

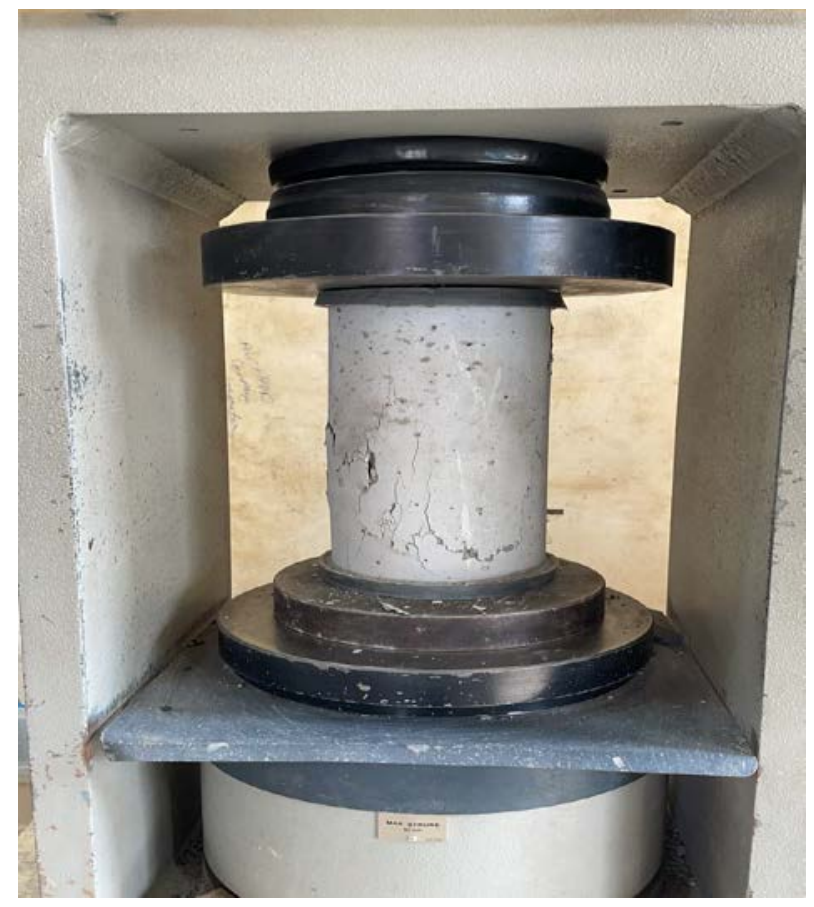

Figure 8. Measurement of compressive strength for PTA concrete specimens 


\subsection{Compressive Strength}

The compressive strength of concrete was evaluated at 7 , 28, and 56 days with 9 concrete cylinders of $150 \mathrm{~mm}$ by $300 \mathrm{~mm}$ dimensions for each of the four mixtures. The compressive strength was evaluated as per ASTM C39 [29]. For each value of compressive strength, the average of three specimens is calculated. An example of the tested specimen with the test equipment for one of the specimens is shown in Figure 8.

\subsection{Results and Discussion}

A total of 36 compressive strength results are listed in Table 2 for the four concrete mixtures at the selected ages. These four concrete mixtures are reference concrete without PTA, concrete with 5\% PTA, concrete with 10\% PTA, and concrete with 15\% PTA. For each set of compressive strength tests, the standard variation and coefficient of variance (\%) were calculated. The results listed in Table 2 show that concrete specimens prepared with 5\% PTA have the highest compressive strength values. When compared to the control mixture (Mix1) specimens, an improvement of $17 \%$ in compressive strength of concrete was measured during the first 7 days. This development in compressive strength continued even after 7 days to reach an $11 \%$ increase at 28 days, and $7 \%$ at 56 days. This improvement in compressive strength can be attributed to the ingredients of PTA which contain $\mathrm{SiO}_{2}$ as reported in previous studies [17]. The existence of $\mathrm{SiO}_{2}$ in PTA can cause pozzolanic reactions in concrete and improve concrete performance.

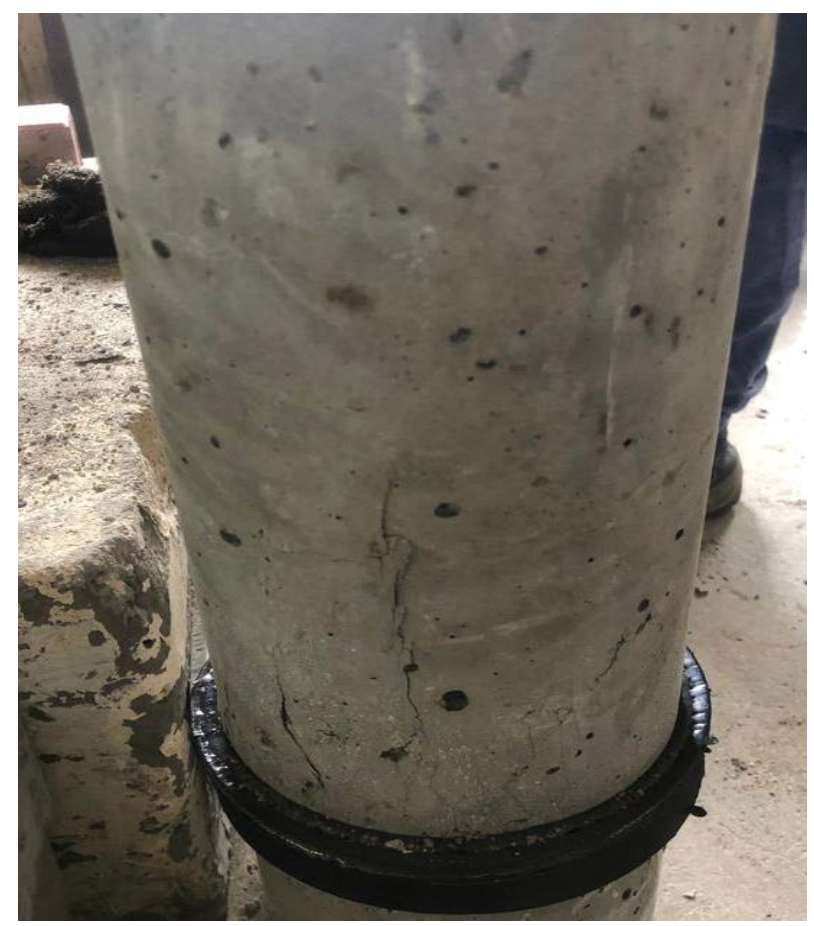

Figure 9. Failure under compressive strength of 5\% PTA concrete specimen at 7 days
For the 10\% PTA concrete specimens a significant reduction in its strength is observed. At 7 days, the reduction in strength value is around $39 \%$ whereas the strength dropped by around $47 \%$ when compared at 28 days. Similarly, the difference between control mix (Mix1) specimens and 10\% PTA (Mix3) reached up to 51\% when measured at 56 days. Thus, the reduction in strength is more prominent at later stages of the hydration process.

The specimens with 15\%PTA experienced similar reductions in strength to those of $10 \%$ PTA concrete. When comparing the 7-day compressive strength between Mix1 and Mix4, the reduction reached up to $47 \%$. At 28 days and 56 days, the reduction in strength was $44 \%$ and $54 \%$, respectively. Thus, a higher reduction in strength is measured even after 28 days when most of the hydration products (about $90 \%$ ) are formed.

The development of compressive strength with time from 7 to 56 days is plotted in Figure 10 for the four mixtures (Mix1 through Mix4). For conventional concrete (OPC) the growth of hydration products and the increase in compressive strength is reasonable. An improvement in the compressive strength of concrete is achieved without affecting the behavior of hydration when only 5\% of PTA is added to concrete. It is safe to suggest adding $5 \%$ or smaller percentages of PTA in concrete. As shown in Figure 10, the 56-day compressive strength in 5\% PTA concrete specimens was measured and found to be 55.3 MPa (about 23.1\% gain from 28-day).

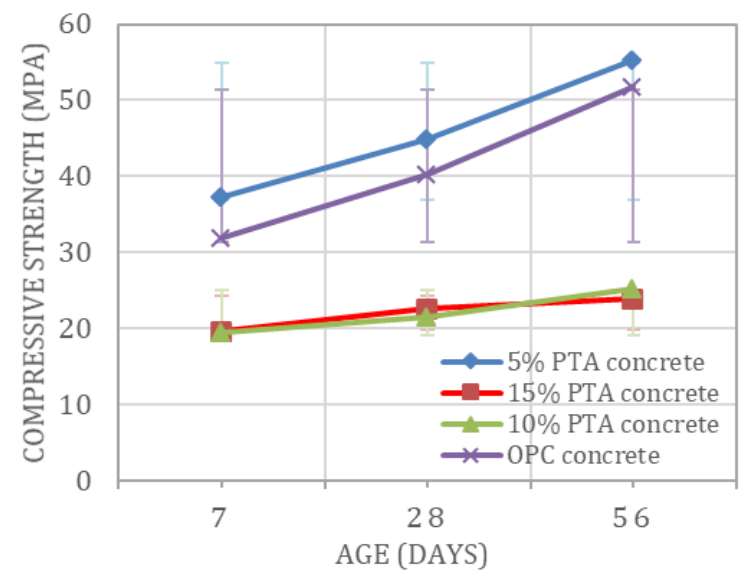

Figure 10. Compressive strength development for tested concrete specimens with time

When the dosage of added PTA to concrete is increased to $10 \%$, the compressive strength and the hydration process are significantly affected as shown in Figure 10. The rate at which the hydration process and gain of compressive strength occur also drops significantly. Similarly, for concrete with $15 \%$ PTA, the gain in compressive strength is much lower than that of the control and 5\% PTA specimens. The rate of compressive strength for $15 \%$ PTA specimens is very similar to that of $10 \%$ PTA. The decrease in compressive strength of 
samples containing $10 \%$ and $15 \%$ PTA is reversed, however, by a slight increase in strength with time as shown in Figure 10.

Results from this study show that an optimal dosage of PTA would be $5 \%$ or lower as a replacement for cement by weight. Although previous studies $[17,18]$ suggested the use of $10 \%$ as an optimal dosage for added PTA, the results of this study suggest avoiding reaching such levels of cement substitution. The reduction in strength when such high amounts of PTA are used is significant and worsens concrete performance under compressive stresses. The contradiction between the current study and previous studies on the optimum dosage of palm tree ash $5 \%$ or
$10 \%)$, can be attributed to many factors. In the current study, only the leaves of the palm tree ash were burned to produce the ash as locally performed in Saudi Arabian farms. The previous studies imported palm tree ash from local recycling plants in Saudi Arabia, where the different parts of the tree are burned and filtered $[17,18]$. Both studies filtered the ash to the same fineness $(420 \mu \mathrm{m})$, but the concrete mixtures and cement contents are different. Previous studies included only $350 \mathrm{~kg}$ of cement while in the current study a higher cement content of $450 \mathrm{~kg}$ is used. The previous studies tested mortar cube specimens whereas the current study tested cylindrical concrete specimens.

Table 2. Compressive strength test results for concrete with different PTA\%

\begin{tabular}{|c|c|c|c|c|c|c|}
\hline$\%$ of PTA & Sample No & Test day & Result, MPa & Average result & Standard deviation & CV\% \\
\hline \multirow{3}{*}{$0 \%$} & A1 & 7 & 33 & \multirow{3}{*}{31.8} & \multirow{3}{*}{1.58} & \multirow{3}{*}{4.99} \\
\hline & $\mathrm{A} 2$ & 7 & 32.4 & & & \\
\hline & A3 & 7 & 30 & & & \\
\hline \multirow{3}{*}{$0 \%$} & $\mathrm{~B} 1$ & 28 & 40.9 & \multirow{3}{*}{40.3} & \multirow{3}{*}{0.56} & \multirow{3}{*}{1.38} \\
\hline & $\mathrm{B} 2$ & 28 & 40.2 & & & \\
\hline & B3 & 28 & 39.8 & & & \\
\hline \multirow{3}{*}{$0 \%$} & $\mathrm{C} 1$ & 56 & 51.4 & \multirow{3}{*}{51.8} & \multirow{3}{*}{0.45} & \multirow{3}{*}{0.87} \\
\hline & $\mathrm{C} 2$ & 56 & 51.8 & & & \\
\hline & $\mathrm{C} 3$ & 56 & 52.3 & & & \\
\hline \multirow{3}{*}{$5 \%$} & $\mathrm{D} 1$ & 7 & 38.5 & \multirow{3}{*}{37.3} & \multirow{3}{*}{1.88} & \multirow{3}{*}{5.05} \\
\hline & D2 & 7 & 35.1 & & & \\
\hline & D3 & 7 & 38.2 & & & \\
\hline \multirow{3}{*}{$5 \%$} & E1 & 28 & 45.2 & \multirow{3}{*}{44.9} & \multirow{3}{*}{0.36} & \multirow{3}{*}{0.80} \\
\hline & E2 & 28 & 45 & & & \\
\hline & E3 & 28 & 44.5 & & & \\
\hline \multirow{3}{*}{$5 \%$} & F1 & 56 & 55.6 & \multirow{3}{*}{55.3} & \multirow{3}{*}{0.92} & \multirow{3}{*}{1.68} \\
\hline & F2 & 56 & 54.3 & & & \\
\hline & F3 & 56 & 56.1 & & & \\
\hline \multirow{3}{*}{$10 \%$} & $\mathrm{~J} 1$ & 7 & 20 & \multirow{3}{*}{19.4} & \multirow{3}{*}{0.56} & \\
\hline & $\mathrm{J} 2$ & 7 & 18.9 & & & 2.87 \\
\hline & $\mathrm{J} 3$ & 7 & 19.3 & & & \\
\hline & $\mathrm{H} 1$ & 28 & 20.6 & & & \\
\hline $10 \%$ & $\mathrm{H} 2$ & 28 & 22.2 & 21.5 & 0.82 & 3.81 \\
\hline & H3 & 28 & 21.7 & & & \\
\hline & G1 & 56 & 26.4 & & & \\
\hline $10 \%$ & G2 & 56 & 25.7 & 25.2 & 1.57 & 6.24 \\
\hline & G3 & 56 & 23.4 & & & \\
\hline & K1 & 7 & 16.1 & & & \\
\hline $15 \%$ & K2 & 7 & 16.4 & 16.6 & 0.62 & 3.77 \\
\hline & K3 & 7 & 17.3 & & & \\
\hline & M1 & 28 & 23.2 & & & \\
\hline $15 \%$ & M2 & 28 & 21.9 & 22.6 & 0.65 & 2.88 \\
\hline & M3 & 28 & 22.6 & & & \\
\hline & N1 & 56 & 23.4 & & & \\
\hline $15 \%$ & N2 & 56 & 22.8 & 23.8 & 1.19 & 5.02 \\
\hline & N3 & 56 & 25.1 & & & \\
\hline
\end{tabular}




\section{Conclusions}

In this study, the compressive strength was assessed for concrete containing palm tree ash (PTA) as a replacement for cement by weight. The compressive strength was measured using concrete cylinders of standard dimensions. A total of 36 concrete cylinders were tested and results of compressive strength are compared to specimens fabricated from a control mixture without PTA. The conclusions that can be drawn from this study are summarized in the following:

- Partial replacement of cement by palm tree ash showed promising potential in improving concrete compressive strength when its small amounts up to $5 \%$ or less are used. The measured compressive strength of 5\% PTA concrete was higher than that of the control concrete without PTA at all ages from 7 to 56 days.

- When higher quantities of PTA (10\% of cement weight or more) are added to concrete, its compressive strength deteriorates and drops by around $50 \%$ at all ages of strength development. Thus, it is recommended to use PTA as cement replacement by less amounts (may be up to 5\%).

- Use of PTA in concrete industry by 5\% replacement of cement will not harm concrete. It will reduce cement consumption and promote recycling of burned palm tree ash in local farms. Further, it will encourage industrializing the process of burning the palm tree branches for sustainable environment.

\section{Acknowledgments}

The authors are very grateful to Alfahd Company, Unyzah, Qassim, Saudi Arabia for their valuable support in fabricating concrete specimens tested in this research.

\section{REFERENCES}

[1] E. Aprianti S., "A Huge Number of Artificial Waste Material can be Supplementary Cementitious Material (SCM) for Concrete Production - a Review Part II," Journal of Cleaner Production, vol.142, pp. 4178-4194, 2017. https://doi.org/10.1016/j.jclepro.2015.12.115.

[2] M.S. Imbabi, C. Carrigan, S. McKenna, "Trends and Developments in Green Cement and Concrete Technology," International Journal of Sustainable Built Environment, vol. 1, no.2, pp, 194-216, 2012. https://doi.org/10.1016/j.ijsbe.2013.05.001.

[3] Mineral Commodity Summaries, USGS. (2021). https://doi.org/10.3133/mcs2021. (accessed Feb 7, 2022)

[4] M.B. Ali, R. Saidur, M.S. Hossain, "A Review on Emission Analysis in Cement Industries," Renewable and Sustainable Energy Reviews, Vol.15, no.5, pp. 2252-2261, 2011. https://doi.org/10.1016/j.rser.2011.02.014.

[5] N. Mahasenan, S. Smith, K. Humphreys, "The Cement Industry and Global Climate Change: Current and Potential Future Cement Industry $\mathrm{CO}_{2}$ Emissions," Greenhouse Gas Control Technologies-6th International Conference, Kyoto, Japan, (1-4 October), 2002, pp. 995-1000. https://doi.org/10.1016/B978-008044276-1/50157-4.

[6] Cement Tracking Report, IEA2020a, (2020). Available at: https://www.iea.org/reports/cement. (accessed Feb 7, 2022)

[7] Hassan, M. Arif, M. Shariq, "Use of Geopolymer Concrete for a Cleaner and Sustainable Environment - A Review of Mechanical Properties and Microstructure," Journal of Cleaner Production, vol. 223, no.1, pp. 704-728, 2019. https://doi.org/10.1016/j.jclepro.2019.03.051.

[8] J. L. Provis, "Alkali-Activated Materials," Cement and Concrete Research, vol. 114, pp. 40-48, 2018. https://doi.org/10.1016/j.cemconres.2017.02.009.

[9] K. McNeil, T. H.-K. Kang, "Recycled Concrete Aggregates: A Review," International Journal of Concrete Structures and Materials, vol.7, no.1, pp. 61-69, 2013. DOI 10.1007/s40069-013-0032-5.

[10] I M. A. K. Salain, "Effect of Water/Cement and Aggregate/Cement Ratios on Consistency and Compressive Strength of Concrete Using Volcanic Stone Waste as Aggregates," Civil Engineering and Architecture, vol. 9, no. 6, pp. 1900-1908, 2021. https://doi.org/10.13189/cea.2021. 090621.

[11] J. P. Gevaudan, W. V. Srubar III, "Energy Performance of Alkali-Activated Cement-Based Concrete Buildings," AEI 2017, Oklahoma City, Oklahoma, April 11-13, 2017. https://doi.org/10.1061/9780784480502.026.

[12] D. Elgheznawy, S. Eltarabily, "A Review of Translucent Concrete as a New Innovative Material in Architecture," Civil Engineering and Architecture, vol. 8, no. 4, pp. 571-579, 2020. https://doi.org/10.13189/cea.2020.080421.

[13] S. A. Zareei, F. Ameri, F. Dorostkar, M. Ahmadi, "Rice husk ash as a partial replacement of cement in high strength concrete containing micro silica: Evaluating durability and mechanical properties," Case Studies in Construction Materials, vol. 7, pp. 73-81, 2017. https://doi.org/10.1016/j .cscm.2017.05.001.

[14] V. G. Chorpade, "Effect of Wood Waste Ash on the Strength Characteristics of Concrete," Nature Environment and Pollution Technology, vol.11, no.1, pp. 121-124, 2012.

[15] S. Chowdhury, A. Maniar, O.M. Suganya, "Strength development in concrete with wood ash blended cement and use of soft computing models to predict strength parameters," Journal of Advanced Research, vol. 6, no. 6, pp. 907-913, 2015. https://doi.org/10.1016/j.jare.2014.08.0 06

[16] M.Z. Al-mulali, H. Awang, H.P.S. Abdul Khalil, Z.S. Aljoumaily, "The Incorporation of Oil Palm Ash in Concrete as a Means of Recycling: A Review," Cement and Concrete Composites. vol. 55, pp. 129-138, 2015. https://doi.org/10.1016/j.cemconcomp.2014.09.007

[17] W. Al-Kutti, A.B.M. Saiful Islam, M. Nasir, "Potential Use of Date Palm Ash in Cement-Based Materials," Journal of King Saud University - Engineering Sciences, vol. 31, no.1, 
pp. 26-31, 2019.https://doi.org/10.1016/j.jksues.2017.01.0 04.

[18] M. Nasir, W. Al-Kutti, "Performance of Date Palm Ash as a Cementitious Material by Evaluating Strength, Durability, and Characterization," Buildings, vol. 9, no.1, pp. 1-13, 2018. https://doi.org/10.3390/buildings9010006.

[19] S. H. Kosmatka, M. L. Wilson, "Chapter 3. Portland, Blended and Other Hydraulic Cement," in Design and Control of Concrete Mixtures, (15th edition), PCA, 2011, pp. 29-63.

[20] V.E. Amah, E. Ugwoha, E. Chukwuemeka, "Effect of Palm Tree Leaf Ash on the Compressive Strength of Concrete and its Workability," The International Journal of Engineering and Science (IJES), vol. 9, no.1, pp 37-45, 2020. DOI: $10.9790 / 1813-0901023745$.

[21] R. Ahmmad, M.Z. Jumaat, S. Bahri, A.B.M.S. Islam, "Ductility Performance of Lightweight Concrete Element Containing Massive Palm Shell Clinker," Construction and Building Materials. vol. 63, pp. 234-241. 2015. https://doi.org/10.1016/j.conbuildmat.2014.04.022.

[22] A.S.M. Abdul Awal, M. Hussin, "Influence of Palm Oil Fuel Ash in Reducing Heat of Hydration of Concrete," Journal of Civil Engineering (IEB), vol. 38, no.2, pp. 153-157, 2010. ISSN 1993-8128.

[23] J. Pone, A. Ash, J. Kamau, F. Hyndman, "Palm Oil Fuel Ash as A Cement Replacement in Concrete," Modern Approaches on Material Science, vol. 1, no.1, pp 1-8, 2018.
DOI: 10.32474/MAMS.2018.01.000102.

[24] P. Premalatha, K.R. Vinodh, L.C. Anto, R. Nithiya, "Properties of Palm Ash Concrete," International Journal of Engineering Science Invention, vol. 5, pp. 29-32, 2016. http://www.ijesi.org/papers/Vol(5)8/version-2/D05080229 32.pdf.

[25] M.Z. Jumaat, U.J. Alengaram, R. Ahmmad, S. Bahri, A.B.M.S. Islam, "Characteristics of Palm Oil Clinker as Replacement for Oil Palm Shell in Lightweight Concrete Subjected to Elevated Temperature," Construction and Building Materials, vol. 101, pp. 942-951, 2015. https://doi.org/10.1016/j.conbuildmat.2015.10.104.

[26] ASTM Standard C33/C33M-18, "Standard Specification for Concrete Aggregates," ASTM International, 2018, DOI: 10.1520/C0033_C0033M-18.

[27] ASTM Standard C192/ C192M-19, "Standard Practice for Making and Curing Concrete Test Specimens in the Laboratory," ASTM International, 2019. DOI: 10.1520/C0192_C0192M-19.

[28] ASTM Standard C511-21, "Standard Specifications for Mixing Rooms, Moist Cabinets, Moist Rooms, and Water Storage Tanks Used in the Testing of Hydraulic Cement and Concretes," ASTM International, 2021. DOI: 10.1520/C0511-21.

[29] ASTM Standard C39/C39M-21, "Standard Test Method for Compressive Strength of Cylindrical Concrete Specimens," ASTM International, 2016. DOI: 10.1520/C0039_C0039 M-21. 